\title{
Aspect-induced differences in soil erosion intensity in a gullied hilly region on the Chinese Loess Plateau
}

\author{
Hai-yan Fang ${ }^{1} \cdot$ Min Guo ${ }^{1,2}$
}

Received: 15 April 2014/ Accepted: 24 May 2015/Published online: 21 June 2015

(C) Springer-Verlag Berlin Heidelberg 2015

\begin{abstract}
Slope aspect exerts important influence on soil erosion intensity and geomorphologic evolution of land surfaces. Using a digital elevation model (DEM $2 \mathrm{~m} \times 2 \mathrm{~m}$ resolution) the gully development intensity in the Wangjiagou catchment on the Chinese Loess Plateau is found to vary as a function of aspect-induced differences in topoclimate. The sunny slopes (i.e., SW, S, and SE aspects) have higher gully erosion intensity than that on the shady slopes (i.e., NE, N, and NW aspects), indicating that southfacing slopes experience faster geomorphic evolution. Variations in process activity can be explained in large part by aspect-induced differences in soil temperature, soil moisture and transpiration, wind force, vegetation coverage and land use pattern on different slope aspects. Lower vegetation coverage and more intensive agricultural activity cause increased erodibility on the sunny slopes. Wind-driven rainstorms can partly explain the higher soil erosion intensity for the sunny slopes, while the impact of mass movement on different slopes is minor. The combination of these factors leads to different soil erosion intensities and geomorphic evolutions on different slopes in the hilly loess region of the Chinese Loess Plateau.
\end{abstract}

Keywords The Chinese Loess Plateau - Slope aspect . Soil erosion intensity . Topoclimate

Hai-yan Fang

fanghy@igsnrr.ac.cn

1 Key Laboratory of Water Cycle and Related Land Surface Processes, Institute of Geographic Sciences and Natural Resources Research, Chinese Academy of Sciences, Beijing 100101, China

2 University of Chinese Academy of Sciences, Beijing 100049, China

\section{Introduction}

Soil erosion is the most important land degradation problem worldwide and is controlled by climatic characteristics, land topography, soil properties, vegetation, and land management (Ethiopia 2001; Ramos and Martínez-Casasnovas 2006; Wilkinson and Humphreys 2006; MartínezMurillo et al. 2013). Slope characteristics, including the aspect, gradient, length, and curvature of the slope, are crucially important in influencing soil erosion and act as important independent variables in many soil erosion models (e.g., ULSE, AGNPS, and ANSWERS) (Merritt et al. 2003). More attention has been paid to the impact of slope aspect on soil erosion in the past decades and progressive achievements have been made. Both Churchill (1982) in Badland National Park (South Dakota, America) and Yair and Lavee (1980) in a badland (North Negev, Isreal) found that soil erosion intensity on the shady slopes is several orders of magnitude greater than that on the sunny slopes as a consequence of the higher antecedent moisture levels and erodible material on the shady slopes. In semi-arid northeastern Arizona, however, the northfacing bedrock slope is moist all year with weak clay expansion, leading to less cliff amount compared to that on south-facing slopes (Burnett et al. 2008). Data from a Mediterranean burnt forest revealed that the sediment yields on south-facing plots are over 6 times higher than those on north-facing plots as a result of the denser plant cover and the thicker soil on the shady slopes (Marqués and Mora 1992). This concurs with studies by Berjak et al. (1986) and Mountain (1952). In Xinzhuang runoff plots on the Loess Plateau, Fang et al. (2011) found that more sediment is generated on the sunny slopes although the generated runoff on sunny slopes is lower than that on shady slopes. Beullens et al. (2014) found that the 
dominant windward side resulted in more rills developed on the southwest slopes. The discrepancies of these viewpoints mentioned above were probably attributed to the critical factor(s) in influencing soil erosion on different slope aspects. However, as mentioned above, the effects of slope aspect on soil erosion mainly focus on the slope surface dominated by sheet and rill erosions, while few studies are conducted at a basin scale and on gully erosion.

Soil erosion on the Chinese Loess Plateau is among the highest in the world, especially in the hilly loess regions with mean annual sediment yield of approximate $1.5 \times 10^{4}$ $\mathrm{t} \mathrm{km}^{-2}$, which acts as a main sediment source of the Yellow River (Huang 1955; Chen 1983; Tang et al. 1991). As a typically hilly loess region of the Loess Plateau, Wangjiagou Catchment was selected in this paper to acknowledge the role that slope aspect plays in influencing soil erosion and geomorphic evolution at a basin scale.

\section{Materials and methods}

\section{Description of the study area}

Wangjiagou River in Lishi County is an effluent of the Beichuan River, located in western Shanxi Province in a hilly loess region on the Chinese Loess Plateau (Fig. 1). Its catchment has an area of $8.8 \mathrm{~km}^{2}$. Mean annual precipitation is $506.5 \mathrm{~mm}, 80.2 \%$ of which falls from May to September. Mean annual evaporation is $1700 \mathrm{~mm}$, approximately three times that of precipitation. Northeastern wind often occurs in spring and southeastern wind often in summer with wind velocity of $3.4-10.7 \mathrm{~m} \mathrm{~s}^{-1}$ and with gusts up to $20 \mathrm{~m} \mathrm{~s}^{-1}$. The period of freezing weather is about 150 days per year, and the freezing depth ranges from 100 to $150 \mathrm{~mm}$.

The main geomorphologic type is made up of mao (meaning isolated hills in Chinese). The difference in elevation ranges from 100 to $300 \mathrm{~m}$. The mean slope gradient for the upper hillslope is about $20^{\circ}$, and the lower generally over $40^{\circ}$. There is an apparent gully edge line for the upper and lower hillslopes.

Food crop is the main land use type. Primary crops include: sorghum (Andropogon sorghum), maize (Zea may LCV), foxtail millet (Setaria italica), soybean (Glycine max), and potato (Solanum tuberosum). Other crops such as wheat (Triticum aestivum), oats (Avena sativa) and crudefiber crops are also planted in the study area. Sixty percent of the catchment is cultivated, and $15-20 \%$ of the croplands are planted on the slopes with gradients greater than $15^{\circ}$. The vegetation coverage is

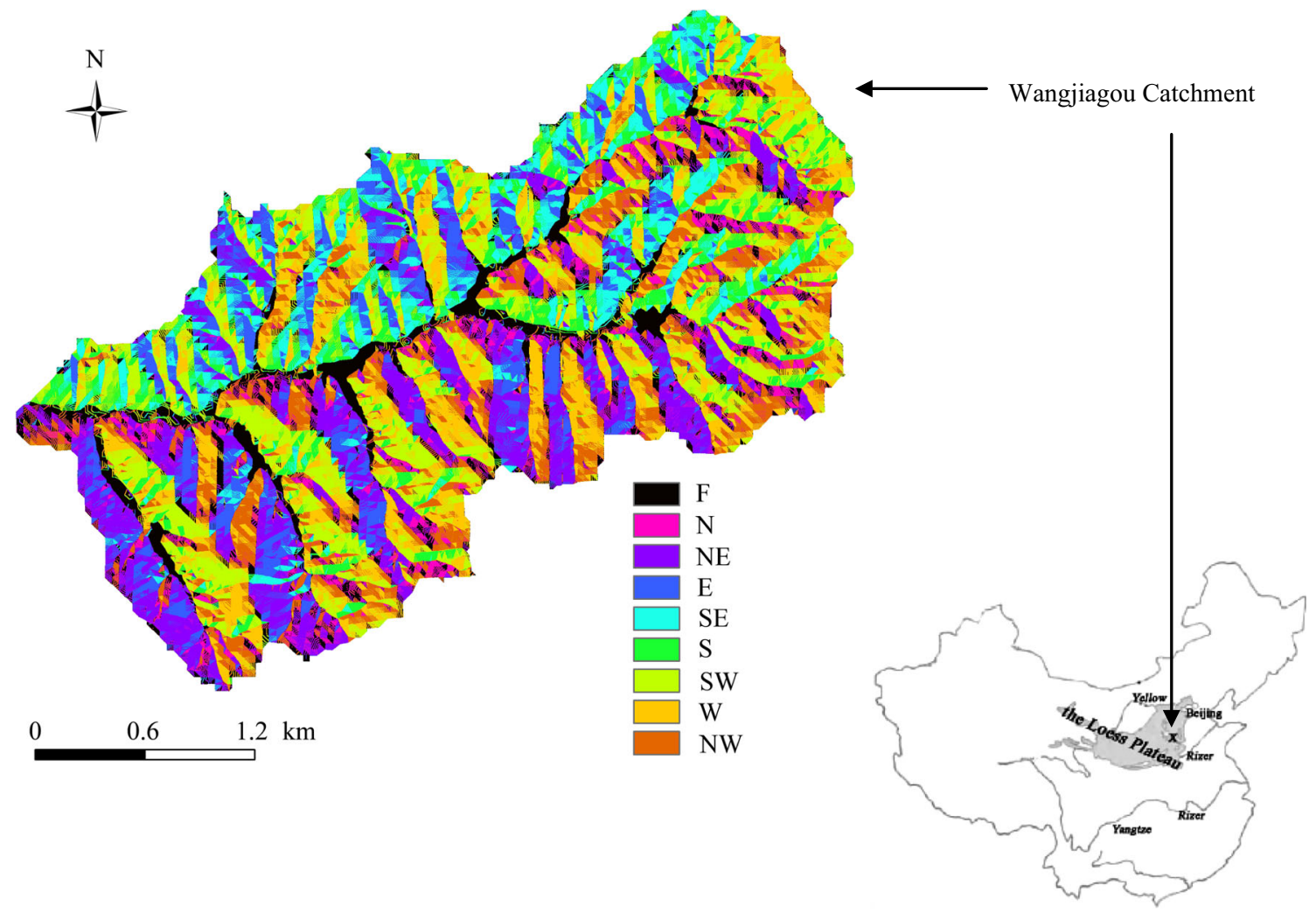

Fig. 1 Location of the study area and its slope aspect differentiation ( $F$ represents flat area, $N, N E, E, S E, S, S W, W$ and $N W$ represent the eight slope aspects, respectively) 
Table 1 Soil mechanical composition, bulk density, soil organic matter and $\mathrm{CaCO}_{3}$

\begin{tabular}{|c|c|c|c|c|c|}
\hline \multicolumn{3}{|c|}{ Soil texture $(\%)^{\mathrm{a}}$} & \multirow[t]{2}{*}{ Organic matter $(\%)^{\mathrm{b}}$} & \multirow[t]{2}{*}{$\mathrm{CaCO}_{3}(\%)^{\mathrm{b}}$} & \multirow[t]{2}{*}{ Bulk density $\left(\mathrm{g} \mathrm{cm}^{-3}\right)^{\mathrm{a}}$} \\
\hline$>0.05$ & $0.05-0.005$ & $<0.005$ & & & \\
\hline 13.5 & 58.1 & 28.4 & 1.0 & 12.1 & $1.13-1.19$ \\
\hline
\end{tabular}

${ }^{a}$ Data comes from Zhu and Zhu (2014)

b Data comes from Luk et al. (1989)
10-20\%. The silt-sized soil is derived from loess deposit, and has a sand content of $13.5 \%$ and a clay content of $28.4 \%$.Soil organic matter content is $1.0 \%$, $\mathrm{CaCO}_{3}$ content is $12.1 \%$, and bulk density ranges from 1.13 to $1.19 \mathrm{~g} \mathrm{~cm}^{-3}$ (Table 1). The sediment yield is severe with a specific sediment yield of ca. $2 \times 10^{4} \mathrm{t}$ $\mathrm{km}^{-2} \mathrm{year}^{-1}$ or even more (Gong and Xiong 1980; Cai et al. 1998).

\section{Data source and treatment}

Using an aerial photo taken in 1999 of the study area, a digital elevation model (DEM) was made with $2 \mathrm{~m} \times 2 \mathrm{~m}$ resolution. ArcGIS 9.3 was used to extract the areas at different slope aspects. The catchment was classified as 8 aspects at $45^{\circ}$ interval, regarding $\mathrm{N}$ as the northern $\left(337.5^{\circ}-22.5^{\circ}\right), \mathrm{NE}$ as the northeastern $\left(22.5^{\circ}-67.5^{\circ}\right), \mathrm{E}$ as the eastern $\left(67.5^{\circ}-112.5^{\circ}\right), \mathrm{SE}$ as the southeastern $\left(112.5^{\circ}\right.$ $\left.157.5^{\circ}\right), \mathrm{S}$ as the southern $\left(157.5^{\circ}-202.5^{\circ}\right), \mathrm{SW}$ as the southwestern $\left(202.5^{\circ}-247.5^{\circ}\right), \mathrm{W}$ as the western $\left(247.5^{\circ}-\right.$ $292.5^{\circ}$ ), and $\mathrm{NW}$ as the northwestern $\left(292.5^{\circ}-337.5^{\circ}\right)$, respectively (Fig. 1).

Steep slope is active in inducing soil erosion for the loose soil. Downslope, the abrupt increase in slope gradient often appears at a gradient of $30^{\circ}-35^{\circ}$. According to the definition by Jiang and Zhao (1966), the area where slope gradient larger than $30^{\circ}$ is regarded as gully slope. Using AcrGIS 9.3, the distribution of the hillslopes larger than $30^{\circ}$ in gradient (i.e., gully slope) was extracted from the DEM (Fig. 2).

By overlapping the area distribution of each aspect in Fig. 1 and the area distribution of gully slope in Fig. 2, the gully slope area for each aspect can thus be obtained by the product of the amount of pixels of gully slope for each aspect and the DEM spatial resolution.

\section{Calculation of developing degree of gully slope}

Gully slope on the Loess Plateau is an important sediment source (Tang 1991; Cai et al. 1998; Xu 1999; Yang et al. 2006). This means that the magnitude of gully slope area is a good indicator of soil erosion intensity. Therefore, the changing ratio of gully slope area to the total area for each aspect can disclose the spatial variability of soil erosion

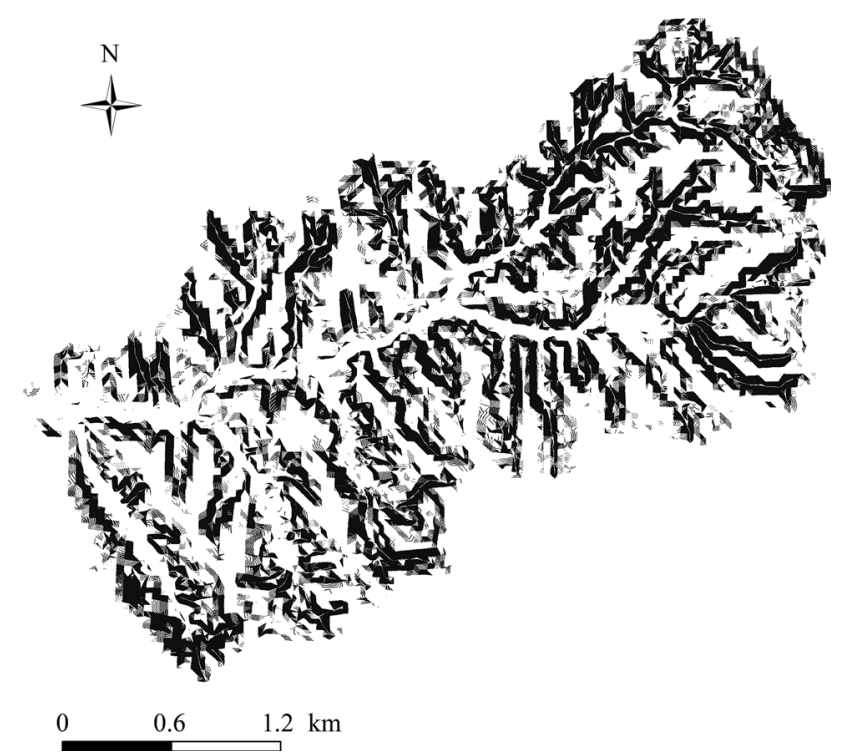

Fig. 2 Gully slope distribution in Wangjiagou Catchment

intensity and evolution of geomorphology and can thus be used to explore the effect of slope aspect on soil erosion intensity. The ratio of gully slope area to the total area is calculated:

$E_{i}=A_{\mathrm{g}} / A$

where $E_{i}$ is developing degree of gully slope in $\%$ for each aspect, $A_{\mathrm{g}}$ is gully slope area in $\mathrm{km}^{2}$ for each aspect and $A$, area of each slope aspect in $\mathrm{km}^{2}$ (Table 2).

\section{Results}

\section{Slope aspect differentiation}

The loess hilly region characterizes an undulant geomorphology with a large area differentiation of slope aspect (Fig. 1). The main slope aspect is in the direction of SW, and the land areas in the $\mathrm{SW}, \mathrm{W}$ and $\mathrm{S}$ slope aspects occupy $15.5,15.7$ and $8.4 \%$ of the total, adding up to $39.6 \%$ of the total for the three slope aspects (Table 2). In contrast, the area for the N-oriented slopes (e.g., the aspects of $\mathrm{N}, \mathrm{NW}$, and NE) is less than $33 \%$ and the area of flat ground only accounts for $8.7 \%$ in the study area. 
Table 2 Land area distributions in different slope aspects in Wangjiagou Catchment

\begin{tabular}{llllll}
\hline Aspect & Flat & $\mathrm{N}$ & $\mathrm{NE}$ & $\mathrm{E}$ & $\mathrm{SE}$ \\
\hline Area $\left(\mathrm{m}^{2}\right)$ & 787,620 & 750,924 & $1,196,188$ & 925,644 & 766,032 \\
Fraction $(\%)$ & 8.7 & 8.3 & 13.2 & 10.3 & 8.5 \\
\hline Aspect & $\mathrm{S}$ & $\mathrm{SW}$ & $\mathrm{W}$ & $\mathrm{NW}$ & Sum \\
\hline Area $\left(\mathrm{m}^{2}\right)$ & 757,704 & $1,401,920$ & $1,418,556$ & $1,011,620$ & $9,016,208$ \\
Fraction $(\%)$ & 8.4 & 15.5 & 15.7 & 11.2 & 100 \\
\hline
\end{tabular}

\section{Developing degree of gully slope}

Gully slope is an important topographic component on the Chinese Loess Plateau, and the $E_{i}$ value reflects the magnitude of erosion intensity. $E_{i}$ differs in different slope aspects and the $E_{i}$ values are higher on the sunny slopes (SE, S, and SW) than that on the shady slopes (NW, N, and NE; Fig. 3). In respect to sunny slopes, the largest $E_{i}$ value of $58.76 \%$ and the second largest one of $55.34 \%$ occur in the directions of SW and SE, respectively, while not in the $\mathrm{S}$ aspect. The $E_{i}$ values for the east- and west-facing slopes are lower than those on the south-facing slopes. The $E_{i}$ value of $32.45 \%$ on northfacing slopes is the smallest one. The different $E_{i}$ values in different slope aspects imply the effect of slope aspect on soil erosion intensity. The discussion in the next section will focus on sunny slope and shady slope in influencing soil erosion intensity.

\section{Discussion}

\section{Slope aspect and hydrothermal status}

The control exerted by slope aspect on soil erosion is related to the receipts of solar radiation on different slopes (e.g., Besler 1987; Sigua and Coleman 2010). Because sunny slopes have higher solar radiation angle and more insolation duration, they can receive higher solar radiation amount than the shady slopes. In the study area, the total amount of solar radiation received on the sunny slopes per day is 1.67 and 1.2 times of those on the shady slopes and on the flat grounds, respectively, and the difference is especially larger in the winter half of the year (Cai et al. 1998). Higher solar radiation makes higher surface temperature and water evaporation. In the acacia (Acacia) forest region of the Chacaizhugou gully of the study catchment, although the sunny and shady slopes have similar ages of Acacia and slope gradients (Yang and $\mathrm{Yu}$ 1992), the water loss in flood season is higher on the sunny slopes than that on the shady slopes, especially in 1989 with $189 \mathrm{~mm}$ water loss on the sunny slopes and $137 \mathrm{~mm}$

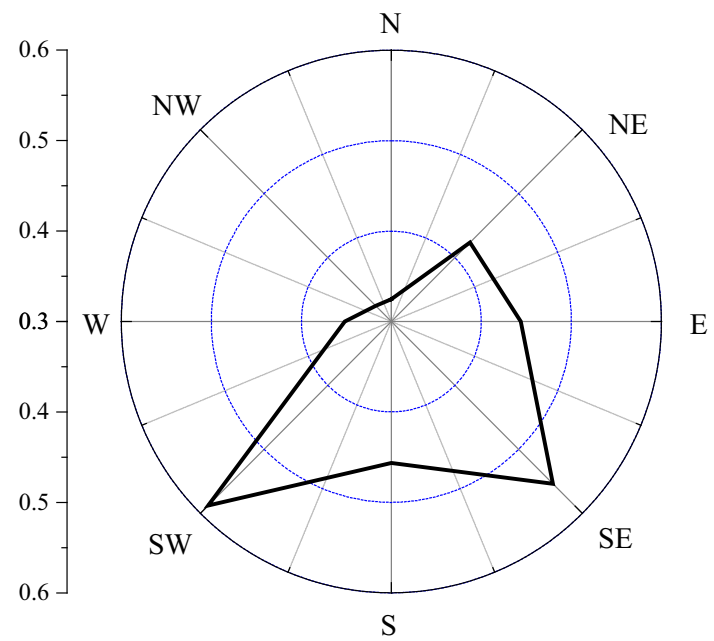

Fig. $3 E_{i}$ rose for different slope aspects in Wangiiagou Catchment

water loss on the shady slopes (Table 3). The difference of water loss results in different moisture regimes on different slopes. The cumulative effect of the moisture difference can alter the gross hydrological balance over an extended period of time (Reid 1973), and the topoclimatic differences may be most pronounced in areas of moisture deficiency where aspect-induced differences in moisture conditions are likely more critical than they would be in areas of abundant moisture (Churchill 1981). In the Guangdaoliang experimental station of the study catchment, the mean soil water content during 1988-1989 differed little on the terrace lands for the sunny and shady slopes, but the soil water content in barren lands on the shady slopes was almost 1.5 times of that on the sunny slopes (Table 4). Fang et al. (2011) also found higher soil water contents on the south-oriented runoff plot in Xinzhuang experimental area. On the Loess Plateau, the climate is semi-arid, and water is a crucial factor in determining vegetation growth. Due to water deficit, mass mortality of infant plants or even mature trees is found in the artificial forest region (He et al. 2006). Different water contents in soil can lead to different vegetation coverage which will influence soil erosion. 
Table 3 Comparison of water loss on slope surfaces due to insolation and water evaporation in the acacia (Acacia) forest regions for sunny (south-facing) and shady (north-facing) slope aspects in Chacaizhugou gully (mm)

\begin{tabular}{rlllllllr}
\hline Year & Age (year) & Slope aspect & Slope angle $\left(^{\circ}\right)$ & \multicolumn{2}{l}{ Flood season (months) } & \multirow{2}{*}{ Sum } \\
\cline { 5 - 8 } & & & & 6 & 7 & 8 & 9 \\
\hline \multirow{2}{*}{1988} & 12 & $\mathrm{~S}$ & 28 & 55.96 & 58.33 & 42.57 & 32.32 & 189.18 \\
& 14 & $\mathrm{~N}$ & 27 & 26.42 & 54.6 & 33.17 & 22.83 & 137.01 \\
1989 & 13 & $\mathrm{~S}$ & 28 & 29.74 & 25.32 & 26.08 & 17.57 & 98.71 \\
& 15 & $\mathrm{~N}$ & 27 & 23.59 & 23.35 & 24.28 & 20.71 & 91.73 \\
\hline
\end{tabular}

Data from Yang and Yu (1992)

Table 4 Annual soil water contents $(\%)$ on the sunny slopes and shady slopes for the $0-200 \mathrm{~cm}$ soil layer in terrace and barren lands in Guandaoliang experimental gully of the study area

\begin{tabular}{llllllrl}
\hline Year & Rainfall $(\mathrm{mm})$ & $\begin{array}{l}\text { Terrace on } \\
\text { sunny slope }\end{array}$ & $\begin{array}{l}\text { Terrace on } \\
\text { shady slope }\end{array}$ & Mean & $\begin{array}{l}\text { Barren land on } \\
\text { sunny slope }\end{array}$ & $\begin{array}{l}\text { Barren land on } \\
\text { shady slope }\end{array}$ \\
\hline 1988 & 610.00 & 16.64 & 17.40 & 17.02 & 11.60 & 16.60 & 14.10 \\
1989 & 402.00 & 11.60 & 12.30 & 12.95 & 10.20 & 13.50 \\
Mean & 506 & 14.12 & 14.90 & 14.99 & 10.90 & 15.05 & 12.98 \\
\hline
\end{tabular}

Data from Cai et al. (1998)

\section{Slope aspect and vegetation}

Vegetation coverage is a crucial factor in controlling soil loss. Soil erosion intensity decreases dramatically with the increase in vegetation coverage on the Chinese Loess Plateau (Shi and Shao 2000; Zhang et al. 2004; Liu et al. 2005; Ran et al. 2013). Vegetation coverage on the Loess Plateau is lower on the sunny slopes with only $10-20 \%$ and higher on the shady slopes with $30 \%$ (Jing et al. 1997). Acacia is one of the major trees planted in Wangjiagou Catchment, occupying $95.6 \%$ of the total woodland areas. Data in Table 5 indicates that $51.36 \%$ of the acacia grows on the shady Mao and shady gully slopes. Due to higher water content on the shady slopes, grass/ shrub vegetation occupies the sunny slopes, while forests are located mainly on the shady slopes. Nyssen and Vermeersch (2010) found correlations between slope aspect and tree cover, with highest tree cover and lower rill erosion on the shady slopes. The higher vegetation coverage leads to higher anti-erosion capacity and lower $E_{i}$ values for the shady slopes than the sunny slope counterparts. The different anti-erosion capacities at different slopes affect geomorphic evolution dynamics.

\section{Slope aspect and wind-driven rainfall erosion}

Slope aspect appears to significantly influence erosion rates (Wilkinson and Humphreys 2006). Besides its impact on underlying characteristics (e.g., hydrothermal status, vegetation cover and soil development), wind-driven rainfall erosion cannot be neglected and has been given much attention to in recent years (e.g., Vieira et al. 2004; Foulds and Warburton 2007; Erkal et al. 2012; Fister et al. 2012). In the Wangjiagou Catchment, the mean monthly wind velocity ranges from 1.7 to $2.5 \mathrm{~m} \mathrm{~s}^{-1}$ in the year period of 1964-1980, with the maximum wind velocity of $15 \mathrm{~m} \mathrm{~s}^{-1}$. In the study area, soil erosion mainly occurs during highintensity rainstorms. When rainstorms happen, the associated wind with it greatly influences soil erosion capacity. Affected by wind action, more rainfall and higher dynamic energy of raindrop erosion occur on the windward slopes than those on the leeward slopes (Iserloh et al. 2013), and wind-driven rainfall erosion processes are geomorphologically important (Vieira et al. 2004).

Using a portable wind and rainfall simulator, Fister et al. (2012) found that soil erosion rates by wind-driven rain are $30-50 \%$ higher than from windless rain. Thus, it can be

Table 5 Area distributions of acacia (Acacia) at different locations for the sunny versus shady slopes in Wangjiagou Catchment

\begin{tabular}{lllllll}
\hline Position & Mao summit & Shady mao slope & Shady gully slope & Sunny mao slope & Sunny gully slope & Bottom of gully \\
\hline Area (ha) & 16.67 & 17.32 & 63.37 & 6.72 & 51.75 & 1.26 \\
Fraction (\%) & 10.61 & 11.02 & 40.34 & 4.28 & 32.95 & 0.80 \\
\hline
\end{tabular}

Data from Yang and Yu (1992) 


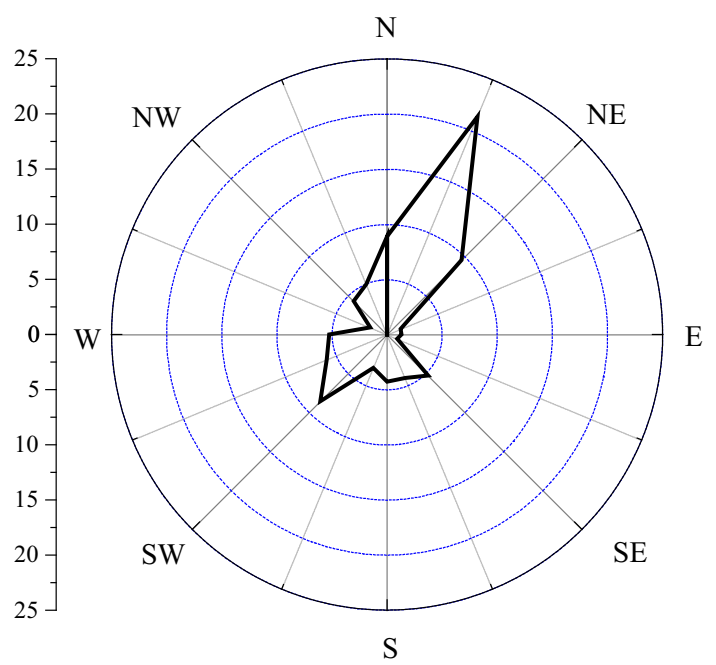

Fig. 4 Wind rose in Wangjiagou catchment made with wind speed larger than $4 \mathrm{~m} \mathrm{~s}^{-1}$ during 1964-1980

imaginable that more intensive soil erosion would occur on the windward slopes than that on the leeward slopes if other factors were the same. Figures 3 and 4 demonstrate that the largest mean annual occurring frequency of NNE wind larger than $4 \mathrm{~m} \mathrm{~s}^{-1}$ in velocity does not lead to the largest $E_{i}$ value, while the locations with the second and third largest mean annual wind velocities correspond with the largest and second largest $E_{i}$ values in the SW and SE directions, respectively. The disparity of the wind and $E_{i}$ rose can be explained in large part by the higher vegetation coverage which partly counteracts the impact of wind action on erosion intensity. Noticeably, although winddriven rain can impact gully development, it cannot control the direction towards the gully head is moving. The head pointing directions of the primary channels and/or gullies obtained from the DEM are quite different from the wind directions (Fig. 5). In water erosion-dominated areas, wind can influence gully development, but it has not enough energy to determine its retreat direction. Chaplot et al. (2011) pointed out that runoff erosion was the dominant mechanism controlling gully retreat, followed by winddriven splash and fall down of aggregates.

\section{Slope aspect and wasting mass movement}

Wasting mass movement, mostly occurring on steep slopes, plays an important role in leading to severe soil erosion. Counts of identifiable mass movement features including predominantly slump scars and mudflow lobes were made for Wangjiagou basin by Zhu (1989). Figure 6 shows that almost all the investigated sub-basins had higher occurring frequency of slumping scenarios on the shady slopes, with mean values of 57 and $43 \%$ on the shady and sunny slopes, respectively. This phenomenon is probably due to lower normal stress resulting from higher soil water content on shady slopes (Luk et al. 1989; Churchill 1982). In the northern Ethiopian highlands, Van Den Eeckhaut et al. (2009) also found that N-oriented slopes have a slightly higher landslide occurring frequency. Burnett et al. (2008) demonstrated that aspect strongly influences slope and cliff processes through differences in soil moisture. However, these enumerative counts alone may fail to expose erosion intensity for the sunny and shady slopes. In the White River Badlands of South Dakota, though nearly $85 \%$ of all slump scars and mudflow lobes occur on the shady slopes, there is little difference in magnitude of failures between shady and sunny slopes (Churchill 1982). In the study area, soil moisture determines vegetation growth and anti-erosion capacity. The higher vegetation coverage due to higher moisture can be hypothesized to counterpart the higher frequency of mass movement scenarios on the shady slopes though no evidence has yet been provided, so that the mass movements does not significantly influence the difference of $E_{i}$ for the sunny and shady slopes.
Fig. 5 The primary channels or gullies distributed within the study catchment (a) and the head directions of the primary channels or gullies (b) (a)

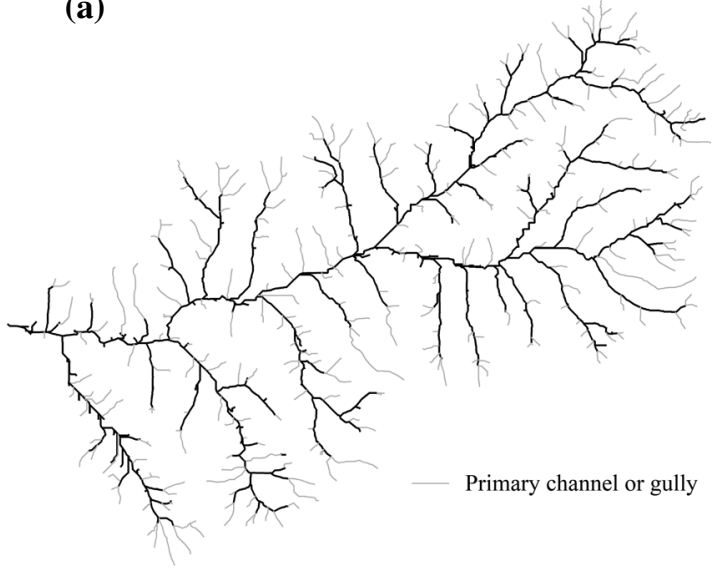

(b)

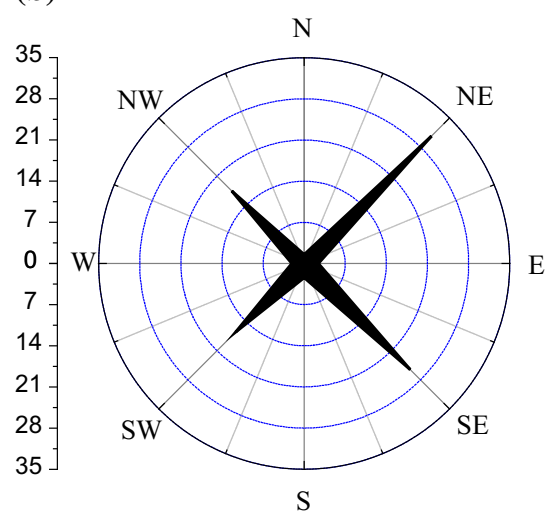




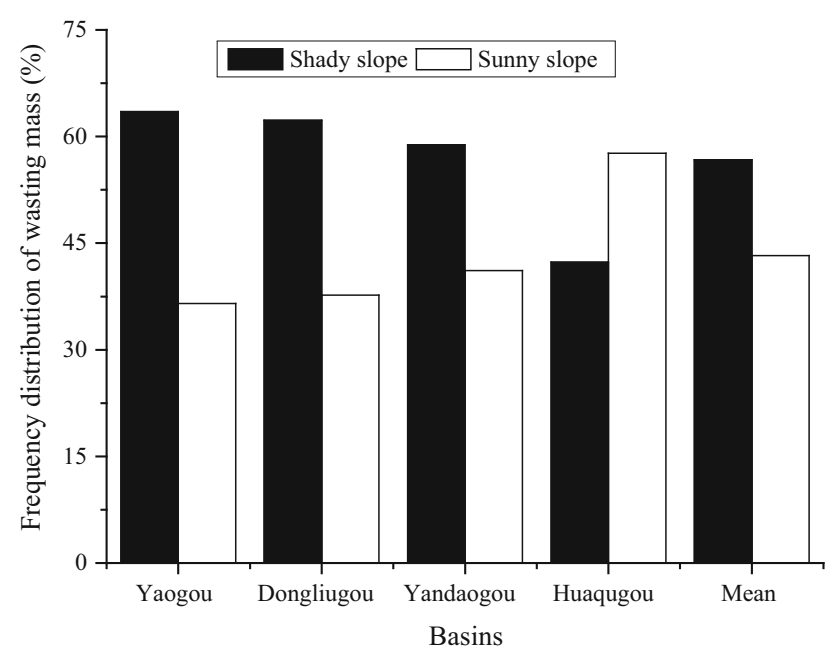

Fig. 6 Frequency distribution of wasting mass movement scenarios for the shady versus sunny slopes in some sub-basins in Wangjiagou Catchment [modified from Zhu (1989)]

\section{Slope aspect and human activity}

Human activity is an important agent in influencing soil erosion (Li 1988; Torri et al. 2013). For higher solar radiation, cropland is first cultivated on the sunny slopes. With increasing population, shady slopes begin to be cultivated. Because of higher water content on the shady slopes, crop yields are higher than those on the sunny slopes (Table 6). The agricultural activities can greatly influence vegetation coverage and anti-erosion capacity of the surface soil, greatly enhancing soil erosion (Fu 1989; Fu and Gulinck 1994; Uri 2001; Chen et al. 2003; Gong et al. 2006). Though cultivated lands increase on the shady slopes with increasing population, the plantation areas for the main crops in the study area on the sunny slopes are still higher than those on the shady slopes (Table 6), which can partly explain the difference in soil erosion intensity on the sunny versus shady slopes.
The difference of soil erosion intensity in different slope aspects is a complicated process determined by erosion capacity of rainstorm/wind, anti-erosion capacity of underlying surface, and human activities since geologic period. Different combinations of the factors mentioned above probably lead to different soil erosion intensities and geomorphic evolutions. For example, in Belgium spoil heaps there is a strong negative correlation between landsliding and tree cover (Nyssen and Vermeersch 2010). However, this is not the case in our present study, implying that other factors would not be neglected when geographic dynamics are studied in respect of slope aspects.

The results in this study are based on a modeling approach and give a qualitative analysis of the effect of slope aspect on soil erosion intensity at a basin scale. Real data from field work are required to validate current study. However, because the $E_{i}$ at different aspects depend on multiple factors mentioned above, and a field work at smaller scales such as at a sub-basin cannot also represent the whole catchment, the real data are not available in current time. Deep studies are required to monitor gully development for the whole basin in the future. However, this paper gives an initial attempt to study gully development intensity at a basin scale. Importantly, it can also serve as an introduction to a new one with experimental work. For example, it can guide plot location in the field to study the effect of slope aspect on runoff and erosion at a plot scale based on the invoked parameter $E_{i}$.

\section{Conclusions}

Slope aspect acts as a macrofactor or integrated factor in influencing soil erosion, and to some extent it controls temperature, evaporation and soil moisture, vegetation coverage, mass movement and human activities etc. Using a 1:13000 digital elevation model (DEM), an agent of

Table 6 Crop yield per ha for the main crops and their spatial distributions in 1994 in Wangjiagou Catchment

\begin{tabular}{|c|c|c|c|c|c|c|c|c|}
\hline \multirow{2}{*}{$\begin{array}{l}\text { Aspect } \\
\text { Crop }\end{array}$} & \multicolumn{3}{|c|}{ Sunny slope } & \multicolumn{3}{|c|}{ Shady slope } & \multicolumn{2}{|l|}{ Dam land } \\
\hline & $\begin{array}{l}\mathrm{YT} \\
\left(\mathrm{kg} \mathrm{ha}^{-1}\right)\end{array}$ & $\begin{array}{l}\text { YS } \\
\left(\mathrm{kg} \mathrm{ha}^{-1}\right)\end{array}$ & $\begin{array}{l}\text { Area } \\
\text { (ha) }\end{array}$ & $\begin{array}{l}\text { YT } \\
\left(\mathrm{kg} \mathrm{ha}^{-1}\right)\end{array}$ & $\begin{array}{l}\text { YS } \\
\left(\mathrm{kg} \mathrm{ha}^{-1}\right)\end{array}$ & $\begin{array}{l}\text { Area } \\
\text { (ha) }\end{array}$ & $\begin{array}{l}\mathrm{Y} \\
\left(\mathrm{kg} \mathrm{ha}^{-1}\right)\end{array}$ & $\begin{array}{l}\text { Area } \\
\text { (ha) }\end{array}$ \\
\hline Foxtail millet (Setaria italica) & 1260 & 1096 & 48.74 & 740 & 601 & 31.58 & - & - \\
\hline Potato (Solanum tuberosum) & 2672 & 1439 & 28.15 & 1950 & 1062 & 18.24 & - & - \\
\hline $\begin{array}{l}\text { Sorghum (Andropogon } \\
\text { sorghum) }\end{array}$ & 2318 & 1762 & 10.22 & 1513 & 948 & 6.62 & - & - \\
\hline Soybean (Glycine max) & 1140 & 975 & 52.94 & 438 & 305 & 34.30 & - & - \\
\hline Maize (Zea may $L C V$ ) & - & - & - & - & - & - & 6032 & 37.29 \\
\hline
\end{tabular}

Dam land is a kind of flat cultivated land on the gully bed artificially made by blocking the eroded materials from slopes and gullies $Y T$ yield for terrace land per ha, $Y S$ yield for sloping land per ha, $Y$ yield for dam land per ha, "_" without plantation for the crop indicated Data from Yang and Yu (1992) 
developing degree of gully slope $E_{i}$ was used to study aspect-induced soil erosion intensity and geomorphic evolution in Wangjiagou Catchment. There exists a great difference of soil erosion intensity at different slope aspects, and $E_{i}$ values on the sunny slopes (including SW, SE and $S$ ) were higher than those on the shady slopes (including NE, N and NW aspects).

Sunny slopes receive higher solar radiation, resulting in higher water loss, lower soil water content and lower vegetation coverage than the counterparts on the shady slopes, and the sunny slopes suffer severer land cultivation compared to the shady slopes. Wind-driven rainfall erosion cannot be neglected in the study region, the largest and the second largest $E_{i}$ values in the SW and SE aspects correspond with the second and third largest annual occurring frequency of the wind larger than $4 \mathrm{~m} \mathrm{~s}^{-1}$ in velocity. Probably influenced by vegetation coverage, wind-derived rainfall erosion and agricultural activity, the mass movement scenarios present a minor effect on aspect-induced soil erosion intensity. The difference of soil erosion intensity is a complicated process determined by the erosion capacity induced by rainstorm and wind, anti-erosion capacity of underlying surface and human activities. Different combinations of the factors mentioned above probably lead to different soil erosion intensities and geomorphic evolutions. Further study on field work monitoring gully development at different slope aspects at a basin scale is urgently required in future.

Acknowledgments This work was financially supported by projects of the National Natural Science Foundation of China (grant numbers 41271305 and 41271304). Special thanks are owed to the anonymous reviewers for their fruitful suggestions to the improvement of the manuscript.

\section{References}

Berjak M, Fincham RJ, Liggit B, Watson HK (1986) Temporal and spatial dimensions of gully erosion in Northern Natal, South Africa. In: Proceedings of an international symposium of International Society for Photogrammetry and Remote Sensing and the Remote Sensing Society. Edinburgh, pp 583-593

Besler H (1987) Slope properties, slope processes and soil erosion risk in the tropical rainfall forest of Kalimantan Timur (Indonesian Borneo). Earth Surf Proc Land 12:195-204

Beullens J, Van de Velde D, Nyssen J (2014) Impact of slope aspect on hydrological rainfall and on the magnitude of rill erosion in Belgium and northern France. Catena 114:129-139

Burnett BN, Meyer GA, McFadden LD (2008) Aspect-related microclimatic influences on slope forms and processes, northeastern Arizona. J Geophys Res 113:F03002. doi:10.1029/ 2007JF000789

Cai QG, Wang GP, Chen YZ (1998) Erosion sediment yield process and simulation of small catchments on the Loess Plateau. Science Press, Beijing, p 192

Chaplot V, Brown J, Dlamini P, Eustice T, Janeau JL, Jewitt G, Lorentz S, Martin L, Nontokozo-mchunu C, Oakes E,
Podwojewski P, Revil S, Rumpel C, Nondi N (2011) Rainfall simulation to identify the storm-scale mechanisms of gully bank retreat. Agr Water Manage 98:1704-1710

Chen YZ (1983) A preliminary analysis of the processes of sediment yield in small catchment on the Loess Plateau. Geogr Res 2:35-47

Chen L, Messing I, Zhang S, Fu BJ, Ledin S (2003) Land use evaluation and scenario analysis towards sustainable planning on the Loess Plateau in China-case study in a small catchment. Catena 54:303-316

Churchill RR (1981) Aspect-related differences in badlands slope morphology. Ann Asso Am Geogr 71:375-388

Churchill RR (1982) Aspect-induced differences in hillslope processes. Earth Surf Proc Land 7:171-182

Erkal AD, Ayala D, Sequeira L (2012) Assessment of wind-driven rain impact, related surface erosion and surface strength reduction of historic building materials. Build Environ 57:336-348

Ethiopia AA (2001) Land degradation: a challenge to Ethiopia. Environ Manage 27:815-824

Fang HY, Cai QG, Li QY (2011) Influence of slope exposure to runoff yield and sediment production in loess hilly region. Soil Water Conserv China 21(5):39-42

Fister W, Iserloh T, Ries JB, Schmidt RG (2012) A portable wind and rainfall simulator for in situ soil erosion measurements. Catena 91:72-84

Foulds SA, Warburton J (2007) Significance of wind-driven rain in the erosion of blanket peat. Geomorphology 83:183-192

Fu BJ (1989) Soil erosion and its control in the Loess Plateau of China. Soil Use Manag 5:76-82

Fu B, Gulinck H (1994) Land evaluation in the Loess Plateau of sever erosion: the Loess Plateau of China. Land Degrad Rehab 5:33-40

Gong SY, Xiong GS (1980) The origin and transport of sediment of the Yellow River. Guanghua Press, Beijing, pp 43-50

Gong J, Chen L, Fu B, Huang Y, Huang Z, Peng H (2006) Effect of land use on soil nutrients in the loess hilly area of the Loess Plateau, China. Land Degrad Dev 17:453-465

He XB, Zhou J, Zhang XB, Tang KL (2006) Soil erosion response to climatic change and human activity during the quaternary on the Loess Plateau, China. Reg Environ Change 6:62-70

Huang BW (1955) Experience and lesson of mapping soil erosion region in middle reaches of Yellow River. Chinese Bull Sci $12: 15-21$

Iserloh T, Fister W, Marzen M, Seeger M, Kuhn NJ, Ries JB (2013) The role of wind-driven rain for soil erosion-an experimental approach. Zeitsch Fuer GeomorphOlogie 57(1):193-201

Jiang DQ, Zhao CX (1966) Preliminary study of sediment source in small catchments of the middle Yellow River. Acta Geogr Sin $1: 20-35$

Jing K, Lu JF, Liang JY (1997) Changing trends and characteristics of erosion environment in the middle reaches of Yellow River. Yellow River Water Conservancy Press, Zhengzhou, pp 72-74

Li XD (1988) The analysis of soil erosion in different slope direction on the Loess Plateau. Soil Water Conserv China 8:52-54

Liu WG, Yang H, Cao YN, Ning YF, Li L, Zhou J, An ZS (2005) Did an extensive forest ever develop on the Chinese Loess Plateau during the past $130 \mathrm{ka}$ ?: a test using soil carbon isotopic signatures. Appl Geochem 20:519-527

Luk SH, Chen H, Cai QG, Jia ZJ (1989) Spatial and temporal variations in the strength of loess soils, Lishi, China. Geoderma 45:303-317

Marqués MA, Mora E (1992) The influence of aspect on runoff and soil loss in a Mediterranean burnt forest (Spain). Catena 19:333-344 
Martínez-Murillo JF, Nadal-Romero E, Regüés D, Cerdà A, Poesen J (2013) Soil erosion and hydrology of the western mediterranean badlands throughout rainfall simulation experiments: a review. Catena 106:101-112

Merritt WS, Letcher RA, Jakeman AJ (2003) A review of erosion and sediment transport models. Environ Model Softw 18:761-799

Mountain ED (1952) Geology of the Keiskammahoek District. In: Mountain ED (ed) The natural history of The Keiskammahoek District. Shuter and Shooter, Pietermaritzburg, pp 8-26

Nyssen J, Vermeersch D (2010) Slope aspect affects geomorphic dynamics of coal mining spoil heaps in Belgium. Geomorphology 123:109-121

Ramos MC, Martínez-Casasnovas JA (2006) Erosion rates and nutrient losses affected by composted cattle manure application in vineyard soils of NE Spain. Catena 68:177-185

Ran LS, Lu XX, Xu JC (2013) Effects of vegetation restoration on soil conservation and sediment loads in China: a critical review. Crit Rev Environ Sci Techn 43:1384-1415

Reid I (1973) The influence of slope orientation upon the soil moisture regime, and its hydromorphological significance. J Hydrol 19:309-321

Shi H, Shao MA (2000) Soil and water loss from the Loess Plateau in China. J Arid Environ 45:9-20

Sigua GC, Coleman SW (2010) Spatial distribution of soil carbon in pastures with cow-calf operation: effects of slope aspect and slope position. J Soil Sediment 10:240-247

Tang KL (1991) Soil erosion on the Loess Plateau: its regional distribution and control. Science and Technology Press, Beijing, p 246

Tang KL, Zhang P, Wang B (1991) Soil erosion and eco-environment changes in quaternary. Quaternary Res 4:300-309

Torri D, Santi E, Marignani M, Rossi M, Borselli L, Maccherini S (2013) The recurring cycles of biancana badlands: erosion, vegetation and human impact. Catena 106:22-30

Uri ND (2001) The environmental implications of soil erosion in the United States. Environ Monit Assess 66:293-312
Van Den Eeckhaut M, Moeyersons J, Nyssen J, Abraha A, Poesen J, Haile M, Deckers J (2009) Spatial patterns of old, deep-seated landslides: a case-study in the northern Ethiopian highlands. Geomorphology 105:239-252

Vieira G, Mora C, Gouveia MM (2004) Oblique rainfall and contemporary geomorphological dynamics (Serra da Estrela, Portugal). Hydrol Process 18:807-824

Wilkinson MT, Humphreys GS (2006) Slope aspect, slope length and slope inclination controls of shallow soils vegetated by sclerophyllous heath-links to long-term landscape evolution. Geomorphology 76:347-362

Xu JX (1999) Grain-size characteristics of suspended sediment in the Yellow River, China. Catena 38:243-263

Yair A, Lavee H (1980) Runoff and erosion processes and rates in the Zin Valley Badlands, northern Negev, Israel. Earth Surf Proc Land 5:205-225

Yang WZ, Yu CZ (1992) Evaluation and Regional Governance on the Loess Plateau. Science Press, Beijing, pp 217-219

Yang MY, Tian JL, Liu PL (2006) Investigating the spatial distribution of soil erosion and deposition in a small catchment on the Loess Plateau of China, using ${ }^{137}$ Cs. Soil Till Res 87:186-193

Zhang B, Yang YS, Zepp H (2004) Effect of vegetation restoration on soil and water erosion and nutrient losses of a severely eroded clayey Plinthudult in southestern China. Catena 57:77-90

Zhu TX (1989) Internal condition for the occurrence of gravitational erosion and the analysis of threshold value in loess regions. In: Chen YZ (ed) Resource of coarse silt and mechanism of sediment yield. Meteorological Press, Beijing, pp 100-111

Zhu TX, Zhu AX (2014) Assessment of soil erosion and conservation on agricultural sloping lands using plot data in the semi-arid hilly loess region of China. J Hydrol 2:69-83 